\title{
Immunogenicity of Oral Vaccine Candidate in Recombinant Lactococcus lactis Expressing HBcAg and IFNa-2b for Hepatitis B Prevention
}

\section{Apon Zaenal Mustopa ( $\sim$ azmustopa@yahoo.com )}

Lembaga IImu Pengetahuan Indonesia https://orcid.org/0000-0001-6614-5518

\section{Lita Meilina}

Indonesian Institute of Sciences Research Center for Biotechnology: LIPI Pusat Penelitian Bioteknologi

\section{Sri Budiarti}

IPB University: Institut Pertanian Bogor

\section{Huda Shalahudin Darusman}

IPB University: Institut Pertanian Bogor

\section{Lita Triratna}

Indonesian Institute of Sciences Research Center for Biotechnology: LIPI Pusat Penelitian Bioteknologi

\section{Arizah Kusumawati}

Indonesian Institute of Sciences Research Center for Biotechnology: LIPI Pusat Penelitian Bioteknologi

\section{Linda Sukmarini}

Indonesian Institute of Sciences Research Center for Biotechnology: LIPI Pusat Penelitian Bioteknologi

Arief Purwo Mihardi

IPB University: Institut Pertanian Bogor

Dian Utami

IPB University: Institut Pertanian Bogor

\section{Original Article}

Keywords: Oral immunization, L. lactis, HBcAg, recombinant vaccine

Posted Date: February 9th, 2021

DOl: https://doi.org/10.21203/rs.3.rs-198617/v1

License: (c) (i) This work is licensed under a Creative Commons Attribution 4.0 International License.

Read Full License 


\section{Abstract}

Background: Hepatitis $B$ is a liver inflammation caused by virus infection leading to acute and chronic conditions. Antigenic compound of HBcAg could induce specific $\mathrm{T}$ and $\mathrm{B}$ cell that generating high immunity response rather than $\mathrm{HBsAg}$. Therapeutic agent for hepatitis and cancer treatment which has been approved by USFDA is Interferon $a-2 b$ (IFNa-2b). This type of class I cytokine plays a role in inhibiting viral replication and modulating adaptive immune system.

Objectives: In this study, we analyzed immunogenicity of recombinant HBcAg and IFNa-2b expressed in L. lactis NZ3900.

Methods: In vivo test was carried out using female Balb/c mice. Antibody responses for oral immunization were quantified as total IgG using ELISA on days 21, 35 and 51 . Safety compound of this oral vaccine candidate was also described by liver and spleen condition after immunization. The differential leukocyte counting was performed to confirm the inflammatory process. Results: Post immunization with L. lactis recombinant strains could induce optimum total humoral immune responses on day 35 , with $\mathrm{IgG}$ concentration at $4.96 \pm 1.03 \mathrm{mg} / \mathrm{mL}$. Single treatment with $\mathrm{HBcAg}$ was more potent in inducing immune response (IgG) rather than HBcAg-IFNa-2b combination. Immunization for 51 days could not alleviate animal body weight in each group. The maintaining IgG production until 51 days was just because lymphocytes activities persisted above $70 \%$. The lymphocytes number which achieved $76.3 \%$ (P2) and 78.3\% (P3) compared to Control group with $62 \%$.

Conclusion: Single treatment with recombinant HBcAg expressed in L. lactis NZ3900 was better inducing IgG production and maintaining for 51 days. This result suggested, L. lactis recombinant strain can be as potential vaccine candidate to induce immune response protecting from hepatitis B virus. Moreover, no organ damage was found in liver and spleen of Balb/c mice.

\section{Background}

Hepatitis B Virus (HBV) is a major cause of hepatocellular carcinoma containing two main structural proteins, Hepatitis B Surface Antigen (HBsAg) and Hepatitis Core Antigen (HBcAg). HBV infection could lead into chronic condition which is a potential cause of cirrhosis and liver failure [1]. Indonesia was the second largest of hepatitis B endemicity in South East ASEAN Region (SEAR) subsequent to Myanmar, with the percentage of $2.5-10 \%[2,3]$. Several hepatitis B treatments have been developed either for prevention or therapeutic effects. HBsAg was the first yeast-derived recombinant vaccine developed since 1982 and it had been decreased the cases of infection significantly. Furthermore, antiviral drugs such as lamivudine, adefovir, entercavir, tenofovir could suppress viral replication, but they could not eradicate the persistence of HBV in cccDNA form, and generate viral resistance for long-term treatment [4], [5]. This data indicated HBV infection should be handled through development of new vaccines that provide better antibody responses. 
$\mathrm{HBcAg}$ has been reported as antigenic compound with high immunity which could induce specific $\mathrm{T}$ and $B$ cell. The first antibody response ( $(\mathrm{gM})$ was specific to $\mathrm{HBcAg}$, whereas antibodies specific to HBsAg and $\mathrm{HBeAg}$ were detected afterwards, and those imply a better prognosis with $\mathrm{HBcAg}$ [4]. Yet, in vivo tests of $\mathrm{HBV}$ vaccine from combination of $\mathrm{HBcAg}, \mathrm{HBsAg}$, and adjuvant (such as saponin-based ISCOMATRIXTM, cytosine-guanine dinucleotide $(\mathrm{CpG})$ ) in transgenic mice, generated humoral and cellular immune responses, HBV specific $T$ and $B$ cell without any liver damage $[6,7]$. Considering all aspects, strong innate immune response is the crucial factor to evoke better effect in eradicating HBV. Type I interferons (IFNa and IFN $\beta$ ) are main effector of innate immunity, therefore United States Food and Drug Administration (USFDA) approved Interferon (IFN) $a-2 b$ as therapeutic agent and 86 countries have been used it for hepatitis and cancer treatments [8]. Currently, vaccine administration was through intanasal or intravena, which was high cost limit and complicate challenges in developing country with dense populations, such as Indonesia. Heretofore, developing an inexpensive and easily administered vaccine is important for HBV treatment.

Lactococcus lactis is gram-positive bacteria and had been used for antigen delivery system through mucosal routes. Recombinant $L$. lactis used to express protein or antigen has several advantages, such as no-endotoxins produced in L. lactis, non-pathogenic and non-colonizing characteristic in mucosal tract [9]. Various recombinant antigen expressed in L. lactis had been reported, e.g. nucleocapsid protein of SARS-coronavirus, HIV enveloped-protein, E-domain III of Dengue virus, and they have been tested for intra-vena or oral administration [10]. Moreover, recombinant HBsAg protein has been reported in L. lactis NZ9000 and generated humoral ( $\mathrm{lgG}$ ) and mucosal (IgA) immune response in female Balb/c mice [11]. In Indonesia, dominant detected HBV was sub-genotype B3 in Java Island [12,13]. Additionally, our previous work has been successfully cloned HBcAg of thus sub-genotype into food-grade L. lactis NZ3900 and expressed extracellularly with NICE expression system [14]. However, in vivo test of recombinant HBcAg in $L$. lactis is still limited. Heretofore, in this presence study we reported the immunogenicity of recombinant $\mathrm{HBcAg}$ and combined with recombinant IFNa-2b expressed in L. lactis, which is expected to induce high immune response in female Balb/c mice.

\section{Material And Methods}

\section{Bacterial and Animal Strains}

L. lactis NZ3900 was a host strain used in this study for control treatment. Recombinant HBcAg and IFNa-2b that was successfully cloned into L. lactis using plasmid pNZ8148 $[14,15]$ was obtained from Biotechnology Research Center, LIPI, Cibinong. Specific Pathogen-Free female mice BALB/c 18-25 g (7-8 weeks old) were conducted from Bogor Life Science and Technology (BLST)-IPB University. Procedures related to animal raising and specimen sampling had been received ethic approval from the Animal Ethic Commission decree, number 114-2018 IPB. The guideline refers to PKBPOM No. 17 year 2015. 
To confirm recombinant strain used for immunization, L. lactis pNZ8148-HBcAg and IFNa-2b was analyzed by PCR colony [16] using PnisA (promotor) and TpNZ8148 (terminator) primer. PCR condition for 35 cycles was carried out as follows: pre-denaturation at $94^{\circ} \mathrm{C}$ for $3 \mathrm{~min}$, denaturation at $94^{\circ} \mathrm{C}$ for 1 min, annealing at $55^{\circ} \mathrm{C}$ for $1 \mathrm{~min}$, elongation at $72^{\circ} \mathrm{C}$ for $30 \mathrm{~s}$, followed by a final elongation at $72^{\circ} \mathrm{C}$ for 6 min. PCR product was confirmed in $1 \%$ agarose with ethidium bromide staining.

Host and recombinant $L$. lactis were cultured on M17 enriched with $0.5 \%$ glucose and cultivated on $30^{\circ} \mathrm{C}$ without shaking. Antibiotics and inducers nisin were added to recombinant strains as follows: chloramphenicol $(10 \mathrm{mg} / \mathrm{ml})$ and nisin $(10 \mathrm{ng} / \mathrm{ml})$. Nisin were added when strains growth until $\mathrm{OD}_{600}$ $\sim 0.5$. After induction, strains were incubated for 45 minutes until $\mathrm{OD}_{600} \sim 0.6$. Pellet cells were harvested by centrifugation $3000 \times \mathrm{g}$ at $4^{\circ} \mathrm{C}$ for 10 minutes and washed three times with sterile PBS $1 \times$ [17]. Pellets were suspended in PBS $1 x$ to a final concentration of $10^{14} \mathrm{CFU}$. Total plate counts were implemented to all inoculum to confirm CFU administered for immunization.

\section{Mice immunization and sample collection}

Mice were housed with controlled room temperature $\left(27-28^{\circ} \mathrm{C}\right)$ and sterile water ad libidum in the Educational Animal Hospital, Veterinary Faculty of IPB University. Three groups of mice (5 mice each group) immunized with $10^{14} \mathrm{~L}$. lactis NZ3900 (NC), $10^{14}$ induced recombinant L. lactis HBcAg (P1), and $10^{14}$ induced recombinant $L$. lactis IFNa-2b (P2). One group (P3) of other mice immunized with $10^{14}$ induced recombinant $L$. lactis $\mathrm{HBcAg}$ and IFNa-2b (1:1) suspended in $0.1 \mathrm{ml}$ sterile PBS $1 \mathrm{x}$ and administered orally on day 0, 1, 2, 14-16 and 28-30 [11]. The treatment groups are presented in Table I. Animal body weights were measured before immunized and 7 days after immunization. Serum samples were collected on day 21, 35 and 51. Animal sacrifice was on day 51, and collection of liver and spleen for histopathology analysis.

\section{ELISA}

Quantification of total IgG in serum were analyzed using protocol of protein science, InnoBio. ELISA plates (Costar, Corning Incorporated, NY, USA) were coated with $1 \mu \mathrm{g} / \mathrm{mL}$ IgG capture M8645 in $100 \mu \mathrm{L}$ $0.1 \mathrm{M}$ sodium carbonate-bicarbonate $\left(\mathrm{pH}\right.$ 9.6) per well overnight at $4^{\circ} \mathrm{C}$. Blocking with PBS $1 \mathrm{x}$ containing $10 \%$ skim milk and $0.02 \%$ Tween 20 was carried out at $37^{\circ} \mathrm{C}$ for 90 min. Serum samples $(100 \mu \mathrm{L}$ per well) were added as primary antibodies in triplicate at 1:16000 dilution with PBS 1x. IgG standard was added for serial concentration at $500 \mathrm{ng} / \mathrm{ml}$ to $3.9 \mathrm{ng} / \mathrm{mL}$. The plates were then incubated at $37^{\circ} \mathrm{C}$ for $90 \mathrm{~min}$ following three times washes with $200 \mu \mathrm{L}$ aquabidest containing $0.09 \% \mathrm{NaCl}$ and $0.05 \%$ Tween 20 . Bound antibodies were detected using HRP-conjugated IgG $\gamma$-chain $(1: 2500)$ and then incubated at $37^{\circ} \mathrm{C}$ for 90 min. After washing, ABTS substrates were added $100 \mu \mathrm{L}$ per well and measured at $405 \mathrm{~nm}$. Standard absorbances were plotted to determine equation for IgG concentration.).

\section{White Blood Cells differential count}


The cells were counted using a 40x objective in a strip running the whole length of the film. The film was inspected from the head to the tail and if fewer than 100 cells are encountered in a single narrow strip, one or more additional strips were examined until at least 100 cells have been counted. Each longitudinal strip represents the blood drawn out from a small part of the original drop of blood when it has spread out between the slide and spreader [18].

\section{Liver and spleen histopathology}

To determine safety of recombinant vaccine candidate, we analyzed liver and spleen histopathology in the Primate Animal Study Center, IPB University. Liver and spleen tissue specimen were fixed in Buffer Neutral Formalin (BNF) and embedded in paraffin. $10 \mu \mathrm{m}$ sections of tissue were stained with haematoxylin and eosin (HE) and analyzed descriptively by pathologist. The analysis was emphasized to the presence of mononuclear infiltration cell in the tissue.

\section{Statistical analysis}

Animal body weight changes for 51 days treatment was analyzed using two-way Anova. The antibody responses $(\mathrm{IgG})$ of immunized mice were measured as absorbance which converted into concentration $(\mathrm{ng} / \mathrm{ml})$. The statistical significances were analyzed using One-Way Anova and Tukey post-hoc analysis in SPSS 16.0 program.

\section{Results And Discussion}

One of media for HBV spreading out was from body fluids, e.g. saliva, menstrual, vaginal, and seminal [1]. Most pathogens initiate infection through mucosal site, so early immunization from mucosal tract can increase immunity against infectious agents [19]. In this study, we had been tested immunogenicity of recombinant strain of $L$. lactis containing HBcAg and IFNa-2b in female Balb/c mice. The confirmation of recombinant strain used for immunization through colony PCR, generating confirmed positive band of three colony picked from each strain in Fig. 1. Plasmid without insert gene was confirmed at $440 \mathrm{bp}$ in length (Fig. 1A). The recombinant HBcAg was amplified in $1080 \mathrm{bp}$, and IFNa-2b with $1033 \mathrm{bp}$. The native $\mathrm{HBcAg}$ gene construction in pNZ8148 was 630 bp length, and codon optimized of IFNa-2b was $579 \mathrm{bp}$ in length $[14,15]$. The insert genes were persisted in the Multi Cloning Site (MCS) of pNZ8148 (Fig. 1B).

Four groups were immunized orally with control strain L. lactis NZ3900 and recombinant strains for three times booster in sequence. In day 21, no significant differences of total IgG in each group, and significantly elevated IgG in day 35 for all groups (Table II). In day 51 , IgG change trends with significant difference was pointed out by Control $(P=0.036)$ and $\mathrm{P} 1(P=0.044)$ groups. This statistical analysis result was assumed that Control and P1 groups may be lack to maintain the optimum IgG production up to 51 days, compare to groups which treated with IFNa-2b. Moreover, P3 generated lower IgG concentration compared to HBcAg (P1) or single IFNa-2b (P2) on day 21-51. This data indicated that single treatment with recombinant HBcAg was better to induce high IgG production. To this result, the study reports of 
exogenous $\mathrm{HBcAg}$ was more efficiently presented by $\mathrm{B}$ cell rather than other primary antigen presenting cells (APC), e.g. dendritic cells (DCs) $[20,21]$. The stimulated and activated HBcAg specific B cells could directly differentiate to be mature plasma cell secreting antibodies. Immunogenicity of HBcAg in this study represented as a strong immunogen even without adjuvant. Three dimensions structure of $\mathrm{HBcAg}$ was unique with regular spacing between repetitive spikes on its surface. To those unique features, $\mathrm{HBCAg}$ could induce high number of naïve B cells. The HBcAg-membrane receptor binding could generate intracellular signaling, secretion of IgM and IgG. Furthermore, co-administration of HBcAg and HBsAg has unique effect, while HBcAg could act a potent Th1 adjuvant to HBsAg, besides as immunogenic target [22].

To elicit immune response, several strategies had been developed, such as using of cytokine as adjuvant, e.g. interferon and interleukin [23].. Immunomodulatory effect of IFNa-2b was through activating JAKSTAT pathway and initiated the expression of ISRE regulator gene related to immune regulator protein, e.g. MHC-I [24]. The spontaneous immune responses have been shown depend on the activation of DCs by type I IFNs. Since DCs was reported the most professional APCs, so using proper dose of IFNa-2b for some immunotherapies in DCs activation was so crucial. DCs will act to capture antigen and priming to $T$ cells and activated the naïve $B$ cell to produce antibodies. Regarding to its ability, the dose of recombinant IFNa-2b used in this study may not enough to activate more the immunomodulatory pathway and generate higher IgG production, while combining with efficient immunogen, HBcAg. Moreover, this study also in line to the previous report that explained the innate immune system which may act minor rule compare to immunogenic antigen like HBcAg [20]. Another report showed the coadministration of recombinant HBsAg strain and IFNa-2b enhanced HBsAg specific antibody $\sim 2$ fold higher than single HBsAg [11]. To this data, treated group with recombinant strain may still need more additional dose in enhancing IgG production for 51 days treatment. Furthermore, as a control strain, $L$. lactis NZ3900 also induced better total IgG production compared to the other groups. Lactic Acid Bacteria (LAB) had been proven as immunomodulator based on dose and period of administration [25]. In this study, $10^{14}$ CFU L. lactis NZ3900 could induce total IgG production in serum.

To address the immunity process, we analyzed the differential counts of White blood cells (WBCs). They are heterogenous nucleated cells found in circulation, play a main role of immunity and phagocytosis. WBCs are classified into lymphocytes, monocytes, and granulocytes (eosinophils, basophils, neutrophils) [26]. To determine the number of each WBC on day 51, as the final treatment of immunization, we analyzed differential of leukocyte as the percentage of each type of cell. This analysis related to the total leukocyte count and pointed to analyze inflammatory process. Referring to $\lg G$ concentration, P2 and P3 group did not significantly decrease in day 51 . This data could be related to lymphocytes number which achieved $76.3 \%$ (P2) and 78.3\% (P3) compared to Control group with 62\% (Table III). Maintaining IgG production until 51 days may be caused by lymphocytes activities persisted above $70 \%$, which were analyzed on the last treatment day. Eosinophils and basophils are not circulating, but they act for limit inflammation in the tissue, so there was no detected this kind of leukocytes (Table III). Lymphocytes are known as fundamental cell in cellular and humoral immunity represented a normal percentage at 20-36\% 
in the blood [18]. From this data, co-administration with IFNa-2b could induce more proliferation of lymphocytes $B$ which is responsible to synthesis antibody $(\mathrm{IgG})$ and maintaining this condition for 51 days treatment. Single treatment with $10^{14}$ recombinant HBcAg persisted the IgG production optimum for 35 days and alleviated the IgG concentration on day 51 .

The safety compound of oral vaccine candidate used in this study was analyzed through animal body weights at day 0 and 7 days after immunization (Fig. 2). Statistical significance confirmed weight gain 7 days post-immunization than initial body weight. Oral immunization with recombinant $L$. lactis do not affected the animal appetite, so there are no decreasing body weights after immunization. Additionally, there is no sign of ill-health within the period. Vaccine candidate has non-toxic effect as follows criteria : a) the animal body weight in 7 days after immunization are not less than initial weight, $b$ ) animal death during the testing period is not more than $5 \%$ and does not cause pain after vaccination $[19,20]$. Safety compound of vaccine candidate was also described by tissue and organ condition after immunization. As induction of liver inflammation was the major concern of HBV therapeutic vaccine, so here we reported

analysis of adverse effect on liver tissue by descriptive histopathology analysis based on the presence of inflammatory cell. In the Fig. 3, there were pointed number of mononuclear cells at mild to moderate level. This infiltration was related to lymphocytes aggregates, plasma cell and macrophage in the tissue [29]. The infiltration in all groups was compared to naïve liver tissue of Balb/c mice which generated slight difference. Immunization with L. lactis up 51 days did not generate liver damage to necrosis stage, whereas the period of immunization was classified to chronic immunization up to 90 days treatment [30]. The result indicated that oral vaccine candidate used in this study was not cause liver damage and no adverse effect to liver tissue during treatment. In addition to determine activities of lymphoid system responded to oral vaccine candidate used in this study, we reported spleen histopathology as well. Spleen was the second lymphoid organ and host of all mononuclear phagocyte types i.e. macrophage, dendritic cells and monocytes. As a hosting organ of circulated $\mathrm{T}$ and $\mathrm{B}$ cell for antigen presentation, spleen played a vital role reacting of any antigen exposure [25]. Spleen histopathology in the Fig. 4 described no abnormalities detected of all groups compared to naïve spleen tissue. The result of histopathological description was presented on Supplementary Data 1.

\section{Conclusion}

Recombinant $L$. lactis containing HBcAg has better immunogenicity rather than combined with IFNa-2b as adjuvant. Treatment group with IFNa-2b generated prolonged lymphocytes proliferation up to 51 days. The expressed HBcAg in L. lactis could induce optimal humoral immune response in day 35 without organ damage. Additionally, oral vaccine candidate used in this study was safe, by no lowering body weight for 51 days treatment, implying that recombinant $L$. lactis $\mathrm{HBcAg}$ could be alternative vaccine candidate with strong immunogenicity and easily administered for HBV prevention.

\section{Declarations}

Acknowledgement 
This study was supported by National Program (PN) Obat 2018-2019 of Biotechnology Research Center, Indonesian Institute of Science, Cibinong. We greatly appreciate to drh. Silvia Arin Prabandari, M.Si, ApVet as pathologist, and Primate Animal Study Center, IPB University as institution for histopathology analysis.

\section{Contributions}

AZM and LM planned, designed the research, wrote the manuscript and performed experiments. SB, HSD, APM planned and designed the research. LT, AK, LS and DU performed experiments and analyzed data. All authors read and approved the final manuscript.

\section{Compliance with ethical standards}

\section{Conflict of Interest}

The authors declare that they have no conflict of interest.

\section{Ethical Approval}

This article had been received ethic approval from the Animal Ethic Commission decree, number 1142018 IPB.

\section{Informed consent}

All authors gave their consent for the publishing of the manuscript.

\section{References}

[1] World Health Organization (2018) Hepatitis B. WHO Fact Sheets. https://www.who.int/newsroom/fact-sheets/detail/hepatitis-b. Accessed 03 December 2018.

[2] Kemenkes RI (2014) InfoDATIN: Situasi dan Analisi Hepatitis. Pusat Data dan Informasi. doi: 24427659.

[3] Yano Y, Utsumi T, Lusida MI, Hayashi Y (2015) Hepatitis B virus infection in Indonesia. World J Gastroentero/ 2:10714-10720. doi: 10.3748/wjg.v21.i38.10714.

[4] Ghasemi F, Rostami S, Ghayour-Mobarhan M, Meshkat Z (2016) Current progress in the development of therapeutic vaccines for chronic hepatitis B virus infection. Iran J Basic Med Sci.19:692-704. doi: 10.22038/ijbms.2016.7349.

[5] Jianqiang Li, Mengru Bao, Jun Ge, Sulin Ren, Tong Zhou, Fengchun Qi, Xiuying Pu \& Jia Dou (2017) Research progress of therapeutic vaccines for treating chronic hepatitis B, Human Vaccines \& Immunotherapeutics. 13:986-997. doi: 10.1080/21645515.2016.1276125 
[6] Buchmann P, Dembek C, Kuklick L, Jager C, Tedjokusumo R (2013) A novel therapeutic hepatitis B vaccine induces cellular and humoral immune responses and breaks tolerance in hepatitis $B$ virus (HBV) transgenic mice. Vaccine. Elsevier Ltd. 31(8):1197-1203. doi: 10.1016/j.vaccine.2012.12.074.

[7] Li J, Ge J, Ren S, Zhou T, Sun Y, Sun H, Gu Y, Huang H, Xu Z, Chen X, Xu X (2015) Hepatitis B surface antigen ( $\mathrm{HBsAg}$ ) and core antigen ( $\mathrm{HBcAg}$ ) combine $\mathrm{CpG}$ oligodeoxynucletides as a novel therapeutic vaccine for chronic hepatitis B infection. Vaccine. doi: 10.1016/j.vaccine.2015.03.079.

[8] Ningrum RA (2014) Human Interferon Alpha-2b: A Therapeutic Protein for cancer treatment. Hindawi Publishing Corporation Scientifica. 2014:1-9. http://dx.doi.org/10.1155/2014/970315

[9] Robinson K, Chamberlain LM, Lopez MC, Rush CM, Marcotte H, Le RWF Page, Wells JM (2004) Mucosal and cellular immune responses elicited by recombinant Lactococcus lactis strains expressing Tetanus Toxin Fragment. C Infect Immun. 72(5):2753-2761. doi: 10.1128/IAI.72.5.2753-2761.2004

[10] Bahey-El-Din M, Gahan CGM, Griffin BT (2010) Lactococcus lactis as a cell factory for delivery of therapeutic proteins. Curr Gene Ther. 10(1):34-45.7. doi: 10.2174/156652310790945557.

[11] Zhang Q, Zhong J, Huan L. 2011. Expression of hepatitis B virus surface antigen determinants in Lactococcus lactis for oral vaccination. Microbiol Res

Elsevier. 166:111-120 doi: 10.1016/j.micres.2010.02.002.

[12] Thedja MD, Muljono DH, Nurainy N, Sukowati CHC (2011) Ethnogeographical structure of hepatitis B virus genotype distribution in Indonesia and discovery of a new subgenotype, B9. Virology. 156:855-868. doi:10.1007/s00705-011-0926-y.

[13] Purwono PB, Juniastuti, Amin M, Rendra B (2016) Hepatitis B virus infection in Indonesia 15 years after adoption of a universal infant vaccination program: possible impacts of low birth dose coverage and a vaccine-escape mutant. Am J Trop Med Hyg. 95:674-679. doi: 10.4269/ajtmh.15-0121.

[14] Anwar RI, Mustopa AZ, Ningrum RA (2019) Construction and expression of indonesian hepatitis B core antigen ( $\mathrm{HBcAg}$ ) in Lactococcus lactis as potential therapeutic vaccine. Biotechnologia. 100:37-45. doi:10.5114/bta.2019.83210.

[15] Meilina L, Budiarti S, Mustopa AZ, Darusman HS, Triratna, L, Nugraha MA, Bilhaq MS, Ningrum RA (2020) Construction , Expression and Biological Activity of Interferon $\mathrm{a}-2 \mathrm{~b}$ in Lactococcus lactis Against Colorectal Cancer. Mol Biol Rep (Accepted). 1-12.

[16] Woodman ME (2008) Direct PCR of Intact Bacteria ( Colony PCR ). Curr Protoc Microbiol. 1-6. doi: 10.1002/9780471729259.mca03ds9.

[17] Bermudez-Humaran LG, Cortez-Peres NG, Levefre F, Guimaraes V, Rabot S (2005) A novel mucosal vaccine based on live Lactococci expressing E7 antigen and IL-12 induces systemic and mucosal 
immune responses and protects mice against human papillomavirus type 16 -induced tumors. $\mathrm{J}$ Immunol. 175:7297-7302. doi: 10.4049/jimmunol.175.11.7297.

[18] Werman HA, Brown CG (1986) White blood cell count and differential count. Emerg Med Clin North Am. 4:41-58.

[19] Tan A, Koh S, Bertoletti A (2015) Immune response in hepatitis B virus infection. Cold Spring Harb Perspect Med. 5:1-18. doi: 10.1101/cshperspect.a021428.

[20] Lee BO, Amy T, Frelin L, Sallberg M, Jones J, Peters C, Hughes J, Whitacre D, Darsow B, Peterson DL, Milich DR (2009) Interaction of the hepatitis B core antigen and the innate immune system. $J$ Immunol 182(11):6670-6681. doi:10.4049/jimmunol.0803683.

[21] Bach P, Kamphuis E, Odermatt B (2019) Vesicular stomatitis virus glycoprotein displaying retroviruslike particles induce a type I IFN receptor-dependent switch to neutralizing IgG antibodies. J Immunol. 178:5839-5847. doi:10.4049/jimmunol.178.9.5839.9

[22] Aguilar JC, Lobaina Y, Muzio V, Garcia D, Penton E (2018) Development of a nasal vaccine for chronic hepatitis $B$ infection that uses the ability of hepatitis $B$ core antigen to stimulate a strong Th1 response against hepatitis B surface. Immunol Cell Biol. 82:539-546. doi: 10.1111/j.0818-9641.2004.01278.x.

[23] Ningrum RA (2017) Human Interferon Alpha2a as Anti Hepatitis B and C. Indones J Clin Pharm. 6:298-310. doi: 10.15416/ijcp.2017.6.4.298.

[24] Medrano RFV, Hunger A, Mendonca SA, Barbuto JAM, Strauss BE (2017) Immunomodulatory and antitumor effects of type I interferons and their application in cancer therapy. Oncotarget. 8:7124971284doi: 10.18632/oncotarget.19531.

[25] Medina M, Elisa V, Julio V, Raul R, Susana A (2010) Lactococcus lactis as an adjuvant and delivery vehicle of antigens against pneumococcal respiratory infections. Bioeng Bugs. 1:313-325. doi: 10.4161/bbug.1.5.12086.

[26] Briggs C, Bain BJ (2016) Basic Haematological Techniques. Twelfth Ed. Elsevier Ltd.

[27] Momose H, Takuo M, Masaki O (2010) A new method for the evaluation of vaccine safety based on comprehensive gene expression analysis. J Biomed. 2010. doi:10.1155/2010/361841.

[28] Nnamdi OA, Agu RU, Oli UC, Nwoye CU (2015) Safety evaluation in mice of the childhood immunization vaccines from two south-eastern states of Nigeria.

J Trop Biomed. 5:132-137. doi: 10.1016/S2221-1691(15)30157-X.

[29] Patrick DJ, Rebelatto MC. 2015. Toxicologic pathology and background lesion of nonhuman primates. Med Immune. 12:235-255. doi: 10.1016/B978-0-12-

417144-2.00012-3. 
[30] World Health Organization (2015) Guidelines for the prevention, care and treatment of persons with chronic hepatitis B infection. Perancis (FR):WHO.

\section{Tables}

Table 1. Treatment Groups

\begin{tabular}{|ll|}
\hline Group & Treatment \\
\hline Control & L. lactis NZ3900 \\
\hline P1 & Recombinant L. lactis pNZ8148-HBcAg \\
\hline P2 & Recombinant $L$. lactis pNZ8148-IFNa-2b \\
\hline P3 & Recombinant $L$. lactis pNZ8148-IFNa-2b+HBcAg \\
\hline
\end{tabular}

Table 2. Total IgG in serum of Balb/c mice

\begin{tabular}{|llll|}
\hline Group & \multicolumn{3}{l}{ IgG Concentration $(\mathrm{mg} / \mathrm{mL})$} \\
\cline { 2 - 4 } & Day 21 & Day 35 & Day 51 \\
\hline Control & $1.84 \pm 0.332^{\mathrm{a}}$ & $6.23 \pm 0.399^{\mathrm{b}}$ & $5.48 \pm 0.124^{\mathrm{a}}$ \\
\hline P1 & $1.78 \pm 0.112^{\mathrm{a}}$ & $4.86 \pm 0.105^{\mathrm{ab}}$ & $4.18 \pm 0.393^{\mathrm{ab}}$ \\
\hline P2 & $1.64 \pm 0.087^{\mathrm{a}}$ & $5.05 \pm 0.624^{\mathrm{ab}}$ & $4.86 \pm 1.111^{\mathrm{ab}}$ \\
\hline P3 & $1.39 \pm 0.227^{\mathrm{a}}$ & $3.71 \pm 0.879^{\mathrm{a}}$ & $3.56 \pm 0.789^{\mathrm{a}}$ \\
\hline
\end{tabular}

${ }^{a}$ The numbers in the same column followed by different subset letters are significantly different at a test level of $5 \%$ (Tukey interval test).

Table 3. Differential counts of WBCs in serum 


\begin{tabular}{|llll|}
\hline Leukocyte types & Groups & & \\
\cline { 2 - 4 } & Control & $P 2$ & $P 3$ \\
\hline Lymphocytes & $62.00 \pm 6.57^{\mathrm{a}}$ & $76.33 \pm 1.53^{\mathrm{a}}$ & $78.33 \pm 1.15^{\mathrm{b}}$ \\
\hline Monocyte & $3.33 \pm 2.31^{\mathrm{a}}$ & $1.67 \pm 0.58^{\mathrm{a}}$ & $0.33 \pm 0.58^{\mathrm{a}}$ \\
\hline Eosinophils & $0.00 \pm 0.00^{\mathrm{a}}$ & $0.00 \pm 0.00^{\mathrm{a}}$ & $0.00 \pm 0.00^{\mathrm{a}}$ \\
\hline Basophils & $0.00 \pm 0.00^{\mathrm{a}}$ & $0.00 \pm 0.00^{\mathrm{a}}$ & $0.00 \pm 0.00^{\mathrm{a}}$ \\
\hline Neutrophils & $34.67 \pm 4.51^{\mathrm{a}}$ & $22.00 \pm 1.73^{\mathrm{b}}$ & $21.33 \pm 0.58^{\mathrm{b}}$ \\
\hline
\end{tabular}

\section{Figures}
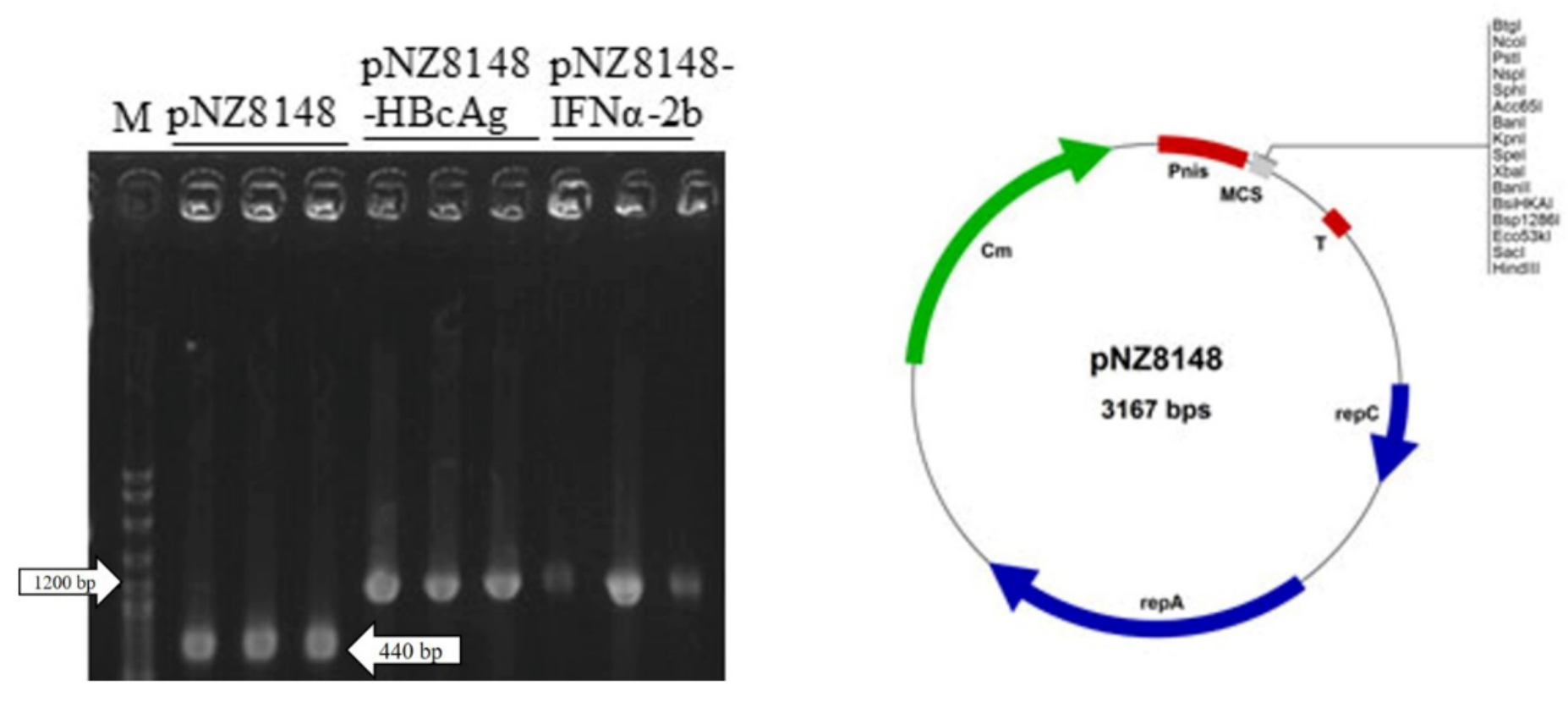

Figure 1

Confirmation of recombinant L. lactis strain of HBcAg and IFNa-2b. (Left) Electrophoregram of PCR product, 100 bp DNA Marker, M (Vivantis). (Right) Plasmid map of pNZ8148 (Mobitec). 


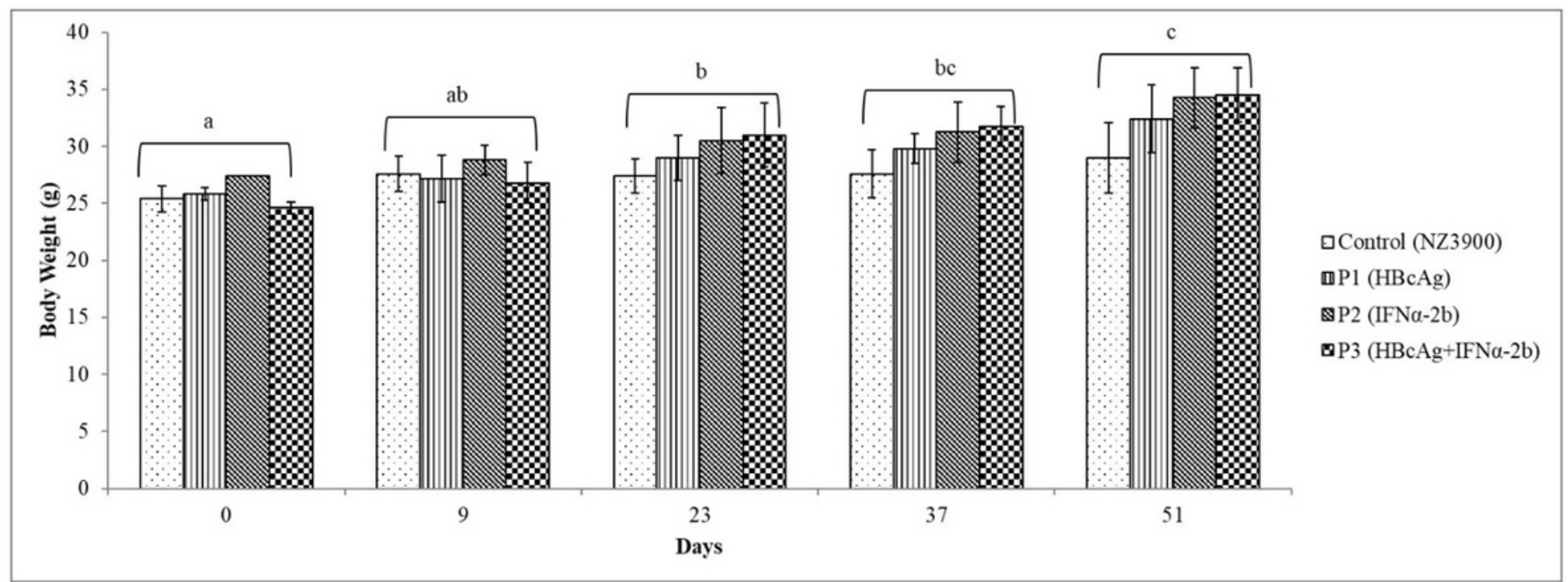

Figure 2

Balb/c mice body weights for 51 days treatment. Different subset letter showed significancy at $5 \%$ level (Tukey interval test).
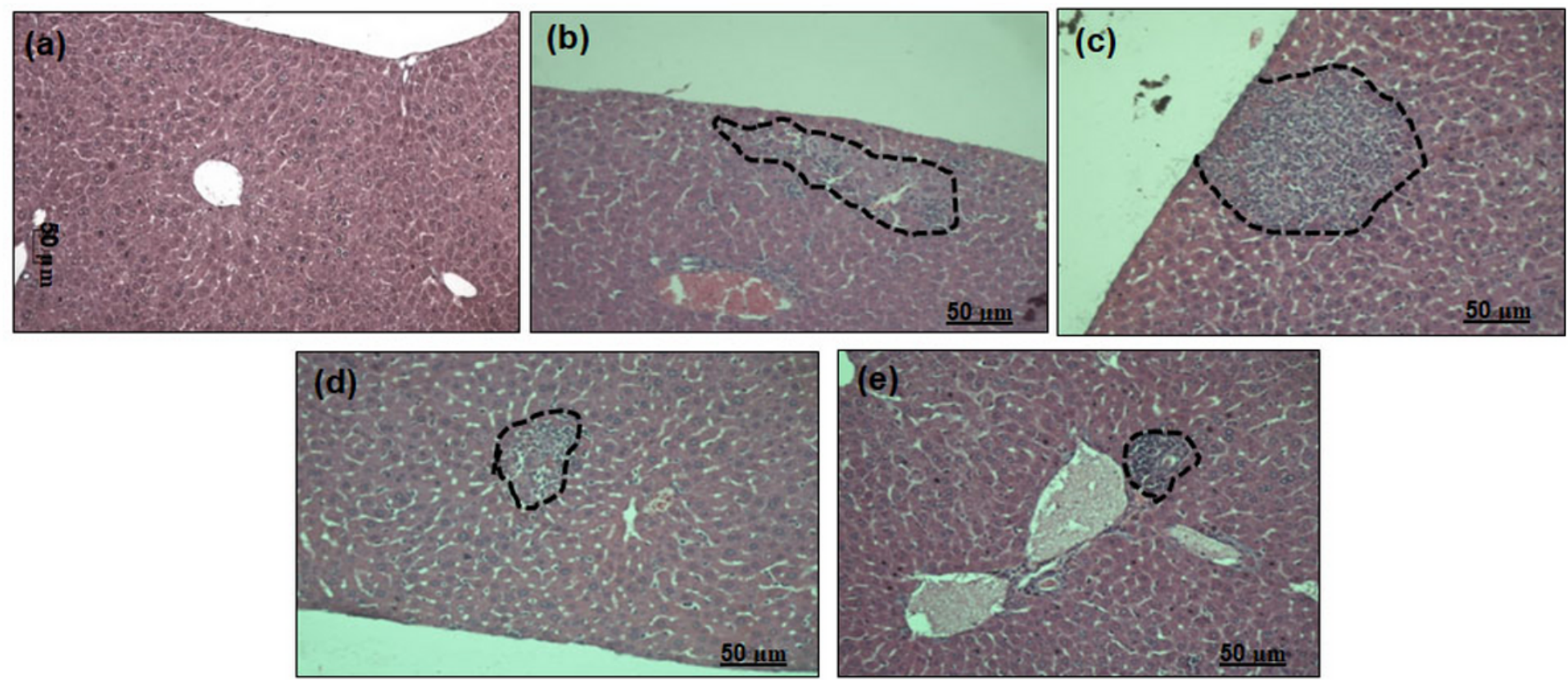

\section{Figure 3}

Liver histopathology of Balb/c mice after immunization with L. lactis in magnitude (20x). (a) Naïve liver; (b) Control; (c) P1; (d) P2; (e) P3. Broken line was represented infiltration area in the tissue. 

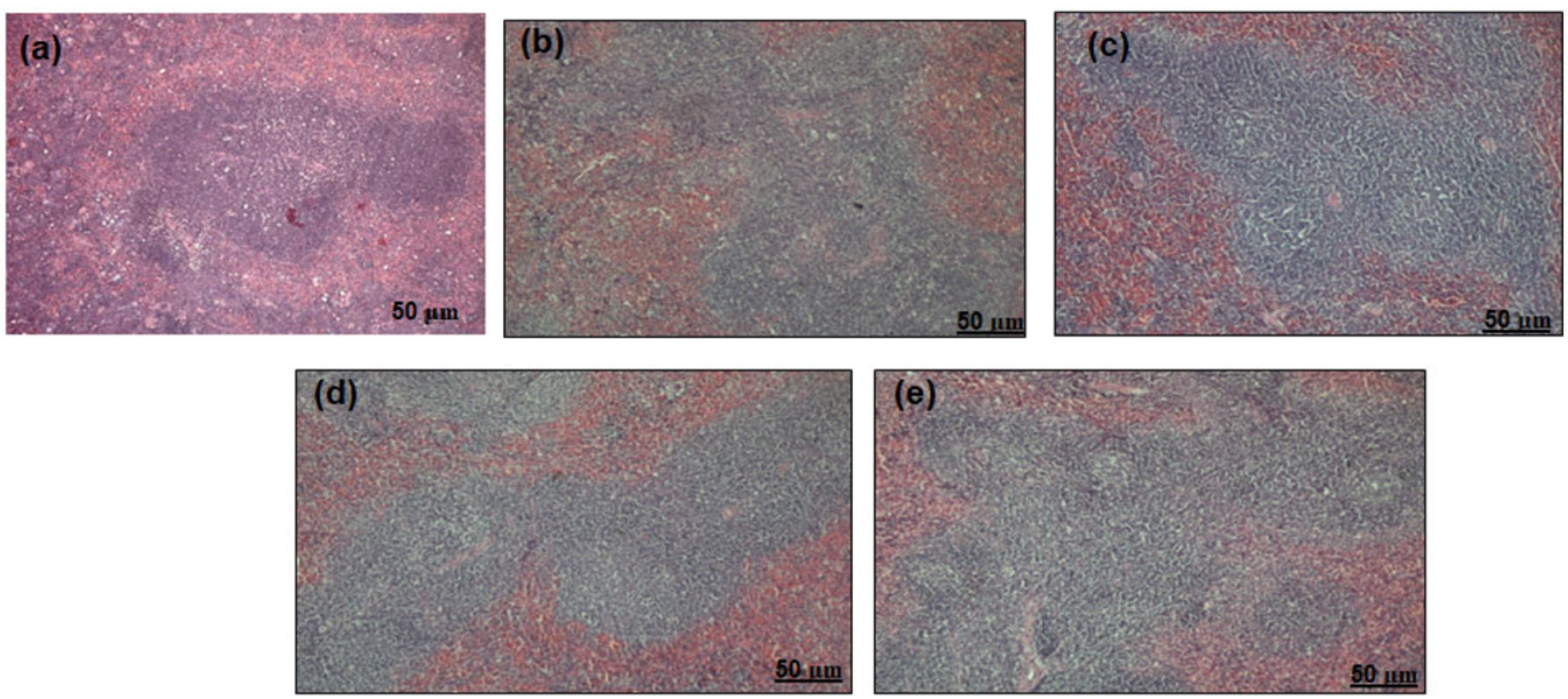

Figure 4

Spleen histopathology of Balb/c mice after immunization with L. lactis in magnitude (20x). (a) Naïve spleen; (b) Control; (c) P1; (d) P2; (e) P3.

\section{Supplementary Files}

This is a list of supplementary files associated with this preprint. Click to download.

- SupplementaryData1.docx 